\title{
Pembelajaran Kooperatif dengan Media Virtual untuk Peningkatan Penguasaan Konsep Fluida Statis Siswa
}

\author{
Nina Nisrina ${ }^{1}$, Gunawan ${ }^{1}$, Ahmad Harjono ${ }^{1}$ \\ ${ }^{1}$ Program Studi Pendidikan Fisika \\ FKIP Universitas Mataram \\ Mataram, Indonesia \\ Email: nnisrina77@yahoo.com
}

\begin{abstract}
Physics is contain a lot of abstract concept.this thing arise student's difficulty in learning physics individually. This difficulty can be solved by educators with using the method of cooperative learning on teaching their pupil. Beside of that, on teaching abstract concept can be helped by using virtual media. Because of that, this research is aim to test the effect of cooperative learning with virtual media toward the student's conceptual understanding in physics on static fluid matter. Pre-test and post-test was gived to experiment and control class. The instrument of the test is conceptual test which consist of six cognitive aspect. The result show that the cooperative learning with virtual media increased student's conceptual understanding in static fluid and significantly increased at sub-matter Archimedes law and fluid pressure. This result also showed the increase of student's cognitive abilty on experiment class, but one of cognitive aspect C6 (create), control class more better than experiment class.
\end{abstract}

Keyword: Cooperative Learning, virtual media, conceptual understanding.

\section{Pendahuluan}

Fisika adalah subjek yang kaya akan pengetahuan dan hukum-hukum fisika yang diformulasikan dalam bentuk matematis. Kemampuan dalam mengkategorikan masalah berdasarkan prinsip-prinsip dasar dibandingkan dengan segala sesuatu yang berhubungan dengan kalimat akan dianggap lebih ahli dalam fisika [1]. Belajar fisika terkait dengan memproleh pemahaman konsep-konsep dasar dan menjadi ahli dalam mengetahui kapan, bagaimana, dan mengapa fisika tersebut diaplikasikan [2]. Selain itu, mata pelajaran fisika di tingkat SMA diajarkan sebagai mata pelajaran yang berdiri sendiri untuk mencapai fungsi dan tujuannya. Salah satu fungsi tersebut adalah menguasai pengetahuan, konsep dan prinsip fisika serta mempunyai keterampilan mengembangkan pengetahuan, keterampilan dan sikap percaya diri sebagai bentuk kreatifitas sehingga dapat diterapkan dalam kehidupan sehari-hari dan sebagai bekal untuk melanjutkan pendidikan pada jenjang yang lebih tinggi [3]. Oleh karena itu, paradigma pembelajaran harus lebih kepada proses pembelajaran yang mengembangkan dan meningkatkan penguasaan konsep siswa. Harus dicatat bahwa, siswa yang mengembangkan penguasaan konsep akan lebih cepat melakukan halhal yang terkait dengan pengetahuan prosedural nantinya dibandingkan dengan siswa yang menghafal dan mengingat saja. Selanjutnya, siswa dengan penguasaan konsep yang bagus akan mampu menyelesaikan secara sempurna segala bentuk tugas yang diberikan dan mampu mengembangkan prosedur-prosedur dan kemampuan mereka yang belum pernah diajarkan [4].

Pada kenyataannya sebagian besar siswa di Indonesia saat ini memiliki tingkat penguasaan konsep yang cukup rendah. Hal ini terbukti dari hasil penilaian PISA pada bidang IPA tahun 2012 menunjukan bahwa Indonesia berada pada tingkat 62 dari 64 negara terhadap tingkat akademik dan penguasaan konsep IPA siswanya [5], dengan 377 PISA score. Survey kedua adalah survey dari TIMSS (Trends International Mathematics Science Survey) tahun 2015 melaporkan nilai rata-rata IPA bidang kognitif menunjukan bahwa Indonesia berada pada peringkat 37 dari 40 negara di dunia dengan standar deviasi lebih kecil dari -1.0[6].

Dengan menurunya tingkat penguasaan konsep siswa pada bidang IPA terutama fisika, maka daya kreativitas mereka juga akan berkurang. Semakin kurang mampunya siswa memahami dan menguasai suatu konsep terutama pada mata pelajaran fisika, maka gagasan-gagasan baru akan sulit timbul dalam diri mereka. Rendahnya penguasaan konsep siswa terhadap pembelajaran fisika kemungkinan besar disebabkan karena anggapan-anggapan dalam diri mereka bahwa pelajaran fisika adalah pelajaran yang sulit, rumit, dan memerlukan daya penalaran yang lebih tinggi disamping mereka harus menguasai matematika sebagai alat bantu dalam memecahkan soal-soal fisika. Fisika juga dianggap kurang menarik bagi siswa sehingga keinginan belajar mereka hampir tidak ada.

Penggunaan model pembelajaran konvensional dalam hal ini yang kita kenal dengan model pembelajaran langsung (direct instruction) cenderung sangat tidak sesuai untuk diterapkan karena informasi tersebut mudah hilang sehingga tidak memiliki arti apa-apa. Instruksi langsung bukanlah untuk meningkatkan penguasaan konsep tetapi lebih kepada menghafal dan mengingat fakta-fakta [4]. Dengan metode ceramah, informasi cenderung hanya dihafal tanpa adanya proses berpikir. Penggunaan model 
pembelajaran langsung cenderung digunakan dalam pembelajaran fisika disebabkan adanya asumsi bahwa pengetahuan dapat dipindahkan secara utuh dari pikiran guru ke pikiran siswa. Siswa yang cenderung menunggu materi yang disajikan oleh guru dan jarang menyelesaikan suatu permasalahan yang terkait dengan kehidupan mereka sehari-hari menyebabkan tingkat pemahaman dan penguasaan konsep mereka menjadi lemah.

Guru harus memiliki pengatahuan tentang bagaimana siswa-siswa tersebut belajar IPA dan Matematika dan bagaimana cara terbaik dalam mengajar. Mengganti cara mengajar dan apa yang diajar dalam IPA merupakan keberlanjutan dari keprofesionalan [4]. Sehingga, dengan meningkatnya jumlah siswa dan metode pembelajaran tradisional tidak efisien lagi, metode pembelajaran alternatif secara luas diterima [2]. Salah satu model pembelajaran yang dipilih peneliti untuk dikembangkan sebagai metode alternatif tersebut guna menjembatani kesenjangan antara kemampuan siswa serta dapat memberikan keleluasan kepada siswa untuk mengembangkan penguasaan konsep mereka terhadap fisika adalah model pembelajaran kooperatif tipe student teams-achievement divisions (STAD). Model pembelajaran kooperatif tipe ini menuntut siswa untuk memecahkan sebuah permasalahan secara kooperatif atau bersama untuk mencapai tujuan bersama dimana setiap anggota kelompok memiliki kemampuan kognitif yang berbeda sehingga dapat meningkatkan penguasaan konsep mereka karena saling bekerjasama.

Secara esensial, pembelajaran kooperatif menyajikan sebuah bagian dalam paradigma pendidikan dari yang awalnya teacher-centered menjadi lebih ke student-centered dalam sebuah grup kooperatif yang menciptakan peluang sempurna bagi siswa untuk menyelesaikan masalah dengan bantuan anggota kelompoknya [4].

Penggunaan media virtual dalam peningkatan penguasaan konsep siswa dalam fisika digunakan karena penyajiannya menarik dan efektif . Terdapat dua jenis media virtual yang digunakan yakni laboratorium virtual dan video virtual. Penggunaan laboratorium virtual digunakan berdasarkan beberapa hal yakni; ketika laboratorium nyata tidak ada persediaan, dan materi yang diajarkan menginginkan variable-variabel hasil praktikum yang banyak [7]. Berdasarkan penelitian Zacharias dan Constantinos, pembelajaran dengan media virtual memberikan hasil yang efektif dalam peningkatan penguasaan konsep.

Pada akhirnya dengan diterapkan model pembelajaran kooperatif berbantuan virtual lab ini, siswa akan lebih mudah memahami konsep materi dalam fisika tanpa dipengaruhi oleh kesenjangan keterampilan mereka, dan mampu meningkatkan penguasaan konsep siswa.

\section{TINJAUAN PUSTAKA}

Pembelajaran kooperatif merupakan pembelajaran yang berpusat pada siswa (student-centered), strategi instruksional dalam bentuk instruktur yang memfasilitasi (instructor-facilitated) dimana terdapat sebuah kelompok kecil yang terdiri dari beberapa siswa yang bertanggung jawab terhadap pembelajaran mereka individual dan anggota kelompok mereka. siswa berinteraksi satu sama lain dalam kelompok yang sama untuk belajar dan mencapai tujuan [8]. Teori utama yang mendasari pembelajaran kooperatif adalah teori social konstruktivisme oleh Vygotsky pada tahun 1986 dimana dia mempertimbangkan bahwa peran budaya, social, bahsa, dan interaksi adalah penting dalam memahami bagaimana mansua belajar [8]. Slavin menjelaskan bahwa pembelajaran kooperatif secara ekstensif, atas dasar teori bahwa siswa akan lebih mudah menemukan dan memahami konsep-konsep yang sulit apabila mereka dapat saling mendiskusikan konsep-konsep yang sulit apabila mereka dapat saling mendiskusikan konsep-konsep itu dengan temannya [9]. Sedangkan model pembelajaran kooperatif tipe STAD yang dikemukakan oleh Slavin adalah sebuah metode pembelajaran yang terdiri dari 4 atau 5 orang yang heterogen dari segi tingkat kemampuan, jenis kelamin, dan latar belakang budaya. Pada STAD yang dinyatakan oleh Slavin bahwa: "Most often, the study involves students discussing problems together, comparing answers, and correcting any misconceptions if teammates make mistakes", yang artinya siswa mendiskusikan masalah bersama, membandingkan jawaban dan memeriksa miskonsepsi jika tim membuat kesalahan. Lima komponen utama dari kooperatif tipe STAD adalah [9] :pertama, presentasi kelas dimana materi diperkenalkan terlebih dulu di dalam kelas yang dapat dilakukan langsung atau dengan audiovisual; kedua, tim yang terdiri dari empat atau lima siswa yang mewakili seluruh bagian dari kelas dalam hal kinerja akademik, jenis kelamin, ras, dan etnisitas. Segala bentuk kegiatan baik praktikum dilakasanakan dalam kelompok/tim kooperatif; ketiga, kuis yang berupa kuis individual yang dilaksanakan setelah guru presentasi dan praktik tim; keempat, skor kemajuan individual yang diberikan sesuai dengan kinerja yang dilakukan siswa dan timnya; dan kelima, rekognisi tim dimana tim akan mendapat penghargaan apabila skor tim mencapai kriteria.

Pembelajaran kooperatif didasari pada kepercayaan bahwa pembelajaran akan menjadi paling efektif ketika siswa secara aktif terlibat dalam berbagi ide dan bekerja secara kooperatif untuk menyelesaikan tugas akademiknya. Pembelajaran kooperatif sudah banyak digunakan sebagai metode 
instruksi dan alat pembelajaran pada berbagai tingkat pendidikan [4].

Keefektifan suatu pembelajaran pada abad 21 ini menjadi lebih baik jika sejalan dengan berkembangnya teknologi dan informasi. Informasi dapat diperoleh dari media cetak maupun media virtual yang merupakan komponen dari teknologi. Hampir seluruh sekolah menggunakan teknologi dalam memperoleh informasi, dari mulai proses pembelajaran ko-kurikuler dan eks-kurikuler.

ICT (Information and Communication Technology) atau yang lebih dikenal sebagai teknologi informasi dan komunikasi dipandang sebagai sebuah alat untuk mendukung pembaruan kurikulum dan keyakinan pedagogic guru dari teacher-centered menuju ke student-centered. Sebagai kegunaan ICT dalam pendidikan, diperoleh daya tarik yang besar dalam pendidikan formal (bagi guru dan bagi siswa), mengajar, dan pembelajaran yang dibingkai dalam satu set proses-transfer ilmu pengetahuan sebagai pelengkap dan penghubung [10]. Salah satu bentuk ICT yang digunakan dalam pembelajaran adalah media virtual.

Banyaknya percobaan yang dilakukan di sekolah biasanya menimbukan keterbatasan yang didasari pada dasar-dasar tertentu seperti infrastruktur yang kurang, alat, waktu dan tempat, serta presisi alat yang kurang. Semua masalah tersebut dapat dihindari dengan percobaan menggunakan laboratorium virtual [11]. Percobaan virtual yang ditampilkan dengan teknologi komputer menambah nilai suatu percobaan fisika dengan mengizinkan siswa untuk mencari fenomena-fenomena yang sulit untuk diobservasi, link yang dapat diobservasi, informasi-informasi yang penting, mengizinkan siswa untuk menciptakan percobaan ganda bahkan lebih hanya dalam waktu yang singkat serta bimbingan yang menarik [12].

Penggunaan media virtual yang dijadikan bantuan dalam pembelajaran kooperatif menjadi solusi untuk meningkatkan penguasaan konsep siswa. Kegiataan penggunaan media virtual diposisikan pada sintaks kedua dari pembelajaran kooperatif tipe STAD yakni pada proses pembelajarannya atau kegiataan inti. Hal ini dilakukan agar siswa mampu menemukan datadata berdasarkan konsep-konsep dari materi yang sudah dipresentasikan sebelumnya oleh guru secara langsung ataupun audiovisual.

Salah satu tuntutan yang paling sering dilakukan dalam pembelajaran kelompok adalah mereka diharuskan belajar dengan memahami dan menguasai konsep. Situatsi dimana mereka harus memiliki kemampuan memahami secara otomatis dan dilakukan setiap saat (situasi dimana kecepatan penalaran ditekankan dengan pemikiran yang luas) sehingga penguasaan konsep dihasilkan dari kemampuan yang procedural untuk mencapai tujuan tertentu [13].
Penguasaan konsep adalah hubungan timbal balik antara unsur-unsur dasar dalam sebuah struktur besar yang berfungsi bersama dalam penggunaanya. Unsurunsur dasar tersebut adalah fakta dari pengetahuan yang harus diketahui siswa untuk mampu menyelesaikan suatu permasalahan tertentu [14]. Sehingga dapat disimpulkan bahwa penguasaan konsep adalah kemampuan siswa dalam menggunakan unsur-unsur dasar dari konsep untuk menyelesaikan suatu permasalahan tertentu. Menurut Krathwohl [14], setelah merevisi taksonomi atau kerangka hasil pembelajaran Bloom, penguasaan konsep merupakan bagian dari pengetahuan, dimana pengetahuan adalah dimensi pertama dari hasil pendidikan dan kognitif adalah dimensi dari pengetahuan terebut. Dimensi hasil kognitif untuk mengukur penguasaan konsep tersebut adalah : remember (mengingat), understand (memahami), apply (mengaplikasi), analyze (menganalisis), evaluate (mengevaluasi), dan create (mencipta).

\section{METOde PENELITIAN}

Penelitian ini dikategorikan sebagai penelitian eksperimen semu (quasi experiment) dengan desain pre-test-post test control group. Populasi penelitian adalah 7 kelas berisi 300 siswa Sekolah Menengah Atas. Sampel penelitian adalah 69 siswa Sekolah Menengah Atas yang dibagi dalam dua kelas yakni 35 siswa dalam kelas eksperimen dan 34 siswa dalam kelas kontrol. Pemilihan sampel dilakukan dengan metode "cluster random sampling". Siswa-siswa tersebut memiliki pengetahuan awal yang hampir sama yang diidentifikasi dari nilai-nilai kognitif mereka sebelum perlakuan. Pada kelas eksperimen diberi perlakukan model pemelajaran kooperatif tipe STAD dengan media virtual dan pada kelas kontrol diberi perlakuan dengan model konvensional atau pembelajaran langsung. Kedua kelas diberikan pre-tes sebelum perlakuan dan pos-tes setelah perlakuan.

Materi pembelajaran yang digunakan adalah fluida statis dengan 5 sub-bab. Media virtual yang digunakan berupa laboratorium virtual dan video virtual. Instumen penelitian berupa tes kognitif pilihan ganda yang soalnya dikategorikan dalam 6 aspek kognitif revisi Bloom oleh Krathwohl [14] yang sudah divalidasi dan diberikan pada saat pre-tes dan pos-tes. Analisis data penguasaan konsep menggunakan uji-t satu pihak dengan taraf signifikan 0,05. Analisis statistik diawali dengan normalitas dan homogenitas data. Proses perhitungan dibantu dengan Microsoft Office Excel 2010. Dalam rangka antisipasi kesalahan penafsiran perolehan skor gain setiap siswa, dihitung besarnya n-gain dengan menggunakan rumus [15]:

$$
N-\text { gain }=\frac{S_{\text {post }}-S_{\text {pre }}}{S_{\text {max }}-S_{\text {pre }}} \times 100 \%
$$




\section{HASIL DAN PEMBAHASAN}

Hasil penelitian ini diperoleh dengan pemberian tes awal dan tes akhir yang berbentuk soal pilihan ganda sebanyak 28 soal untuk mengukur penguasaan konsep siswa dalam materi fluida statis dengan tujuan untuk menganalisis penguasaan konsep siswa dengan menerapkan model kooperatif berbantuan media virtual yang melibatkan kelas eksperimen dan kelas kontrol. Berdasarkan pemberian tes awal dan tes akhir pada kedua kelas terlihat bahwa adanya peningkatan penguasaan konsep kedua kelas yang terlihat pada Tabel 1.

Tabel 1. Perolehan Skor Rata-rata Kedua Kelas

\begin{tabular}{lll}
\hline \multirow{3}{*}{ Eksperimen } & Awal & 30 \\
& Akhir & 81 \\
Kontrol & Awal & 41 \\
& Akhir & 69 \\
\hline
\end{tabular}

Data pada tabel 1 menjadi bukti bahwa pengaruh model pembelajaran kooperatif tipe STAD dengan bantuan media virtual terhadap penguasaan konsep fisika siswa lebih baik dibandingkan dengan pengaruh model pembelajaran langsung. Model pembelajaran kooperatif memberikan kesempatan pada siswa untuk meningkatkan kemampuan dalam memahami suatu konsep dan menguasainya dengan baik karena mereka dapat bekerja secara kooperatif dan saling melengkapi. Jika hanya belajar secara individual, maka peningkatan kemampuan siswa akan hanya terjadi pada siswa pintar saja. Hal ini dibuktikan oleh tabel 1 yang menunjukan skor terendah siswa pada kelas kontrol setelah pos-tes yang hampir sama dengan rata-rata skor terendahnya setelah pre-tes yakni 41, sedangkan skor tertingginya jauh lebih besar dibandingkan perolehan skor terendahnya sehingga standar deviasinyapun besar.

Terlihat bahwa model pembelajaran kooperatif tipe STAD lebih efektif dibandingkan hanya dengan pembelajaran langsung saja. Pembelajaran langsung menuntut siswa untuk menghafal tanpa harus memahami konsep terlebih dahulu, sehingga informasi yang didapatkan akan mudah hilang. Sesuai dengan pernyataan Effandi and Iksan (2006), bahwa intruksi langsung bukanlah untuk meningkatkan penguasaan konsep tetapi lebih kepada menghafal fakta-fakta. Berbeda halnya dengan kooperatif, siswa belajar secara kooperatif dengan siswa lain untuk saling berbagi pemahaman dengan bantuan guru sebagai fasilitatornya. Hasil ini sesuai dengan penelitian yang dilakukan oleh Effandi and Iksan [4] yang meneliti tentang perspektif setiap orang atau pendidik mengenai pembelajaran kooperatif untuk sains yang menyatakan bahwa pembelajaran kooperatif sangat bagus untuk peningkatan kemampuan penguasaan konsep dan penyelesaian masalah sains. Begitu pula dengan hasil penelitian yang disimpulkan oleh Effandi [4] yang menyatakan bahwa dengan menggunakan STAD untuk 1180 siswa dari 18 sekolah ditemukan dapat meningkatkan kemampuan saintifik, dan ketertarikan mereka dalam belajar berkelompok lebih tinggi.

Materi yang digunakan dalam proses pembelajaran adalah materi fluida statis dengan enam sub-materi yakni hukum utama hidrostatis, tekanan hidrostatis, prinsip Archimedes, prinsip pascall, gejala kapilaritas dan tegangan permukaan serta viskositas dan hukum stokes. Presentase peningkatan penguasaan konsep siswa kelas kontrol dan kelas eksperimen dapat diliihat dalam grafik berikut.

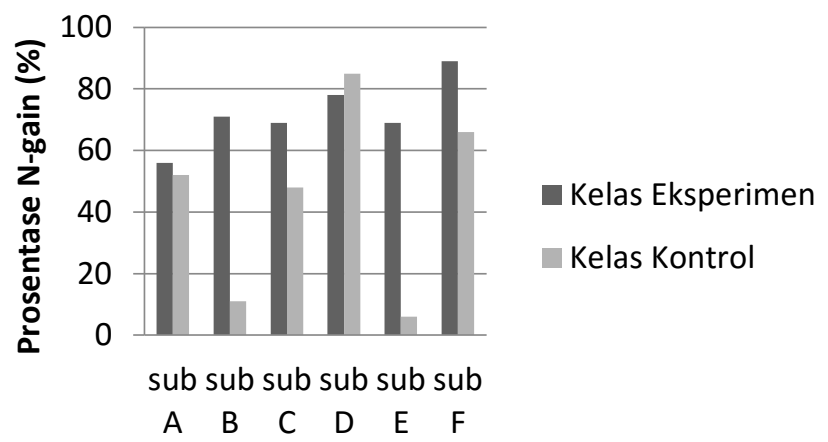

Grafik 1. Perbandingan peningkatan penguasaan konsep siswa eksperimen dan kontrol pada setiap submateri.

Tabel 2. Perolehan Skor N-Gain Kedua Kelas

\begin{tabular}{lcc} 
& Kelas Eksperimen & Kelas Kontrol \\
\cline { 2 - 3 } Sub Materi & N-gain (\%) & N-gain (\%) \\
\hline $\begin{array}{l}\text { Hukum Utama } \\
\text { Hidrostatis } \\
\text { Tekanan }\end{array}$ & $56 \%$ & $52 \%$ \\
$\begin{array}{l}\text { Hidrostatis } \\
\text { Hukum Pascall }\end{array}$ & $71 \%$ & $11 \%$ \\
$\begin{array}{l}\text { Hukum } \\
\text { Archimedes }\end{array}$ & $78 \%$ & $48 \%$ \\
Tegangan & $69 \%$ & $85 \%$ \\
$\begin{array}{l}\text { Permukaan dan } \\
\text { Gejala }\end{array}$ & & $6 \%$ \\
$\begin{array}{l}\text { Kapilaritas } \\
\text { Viskositas dan } \\
\text { hukum Stokes }\end{array}$ & $89 \%$ & \\
\hline
\end{tabular}

Berdasarkan analisis pada grafik penguasaan konsep untuk setiap materi dapat diketahui bahwa peningkatan tertinggi pada kelas eksperimen adalah 89\% pada materi viskositas dan hukum Stokes, sedangkan terendah pada materi gejala kapilaritas dan tegangan permukaan sebesar 69\%. Pada kelas kontrol peningkatan tertinggi pada materi hukum Archimedes sebesar $85 \%$ dan terendah pada materi tegangan permukaan dan gejala kapilaritas sebesar 6\%. Sedangkan untuk materi awal seperti hukum utama hidrostatis untuk kelas eksperimen dan kelas kontrol berada pada prosentase sekitar 54\% yang merupakan rata-rata dari seluruh prosentase sub-materi. 
Peningkatan tertinggi pada materi-materi akhir seperti viskositas hukum stokes untuk kelas eksperimen dapat disebabkan oleh ilustrasi video virtual yang jelas dan lebih banyak dibandingkan dengan materi yang lain, selain itu perhatian siswa lebih berfokus pada satu konsep yakni viskositas. Sedangkan untuk sub-materi gejala kapilaritas dan permukaan mengalami penurunan yang kemungkinan disebabkan oleh konsentrasi siswa yang kurang karena berfokus pada dua konsep sekaligus dalam satu pertemuan.

Dalam grafik untuk sub-materi hukum Archimedes tampak pula bahwa prosentase kemampuan penguasaan konsep siswa kelas eksperimen lebih rendah dibandingkan dengan kelas kontrol. Hal ini kemungkinan terjadi karena kelas eksperimen melaksanakan praktikum virtual dan konsep yang disajikan secara garis besar saja sehingga siswa kurang konsentrasi pada konsep dan hanya fokus pada pengambilan data saja dan langsung latihan dengan contoh soal, sedangkan kelas kontrol diberikan penjelasan secara langsung disertai dengan contoh-contoh soalnya. Tetapi siswa pada kelas eksperimen lebih memahami dan mampu mengevaluasi pembelajaran dengan baik karena melakukan praktikum dengan media virtual sehingga kemampuan mengidentifikasi variabel-variabel yang diminta untuk materi archimedes lebih bagus dibandingkan dengan kelas kontrol. Hal ini terbukti dari rata-rata prosentasi C5 (evaluasi) kelas eksperimen tidak jauh berbeda dengan kelas kontrol untuk materi Archimedes yang dapat dilihat pada grafik 2 untuk sebaran kognitifnya.

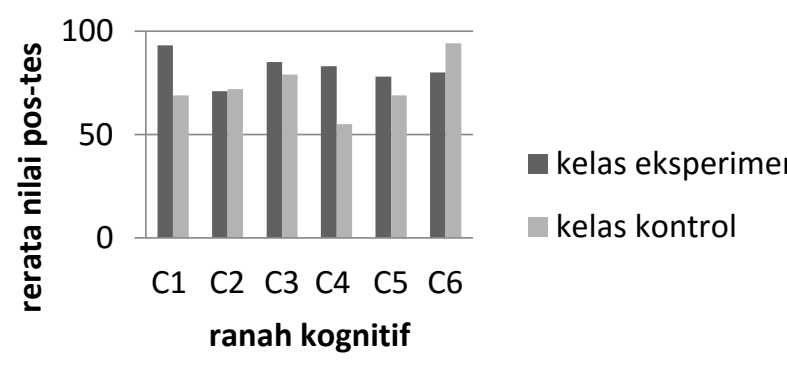

Grafik 2. Tingkatan sebaran kognitif untuk hasil pos-tes penguasaan konsep

Grafik 2 mengidentifikasikan bahwa sebaran kognitif pada C1 sampai dengan C6 di kelas eksperimen dan kelas kontrol. Rata-rata yang diperoleh untuk komponen kognitif mengingat terlihat kelas eksperimen lebih tinggi dengan selisih 24\% dari kelas kontrol setelah diberi perlakuan. Untuk komponen memahami (C2) teridentifikasi bahwa kelas kontrol memiliki prosentase yang lebih tinggi dengan selisih $1 \%$ dari kelas kontrol. Hal ini kemungkinan diakibatkan adanya beberapa siswa yang kurang mampu memahami konsep pada hukum
Pascall karena C2 berada pada soal untuk hukum Pascall. Namun model pembelajaran kooperatif tipe STAD dengan media virtual memberikan pengaruh besar untuk kelas eksperimen pada hukum Pascall yang dibuktikan pada prosentase sub-materi untuk hukum Pascall di grafik 1dengan selisih perbedaan $35 \%$ dengan kelas kontrol.

Untuk komponen aplikasi (C3) kelas eksperimen memiliki prosentase lebih banyak dibandingkan dengan kelas kontrol, begitupula dengan komponen analisis (C4) dan evaluasi (C5) dimana prosentase kelas eksperimen lebih tinggi dibandingkan dengan kelas kontrol. Tetapi untuk komponen C6 yakni mencipta, kelas kontrol memiliki prosentase lebih tinggi dibandingkan dengan kelas eksperimen tetapi tidak memiliki selisih yang besar. Hal ini kemungkinan disebabkan karena model pembelajaran kooperatif dan model pembelajaran langsung/konvensional memiliki pengaruh yang sama pada siswa dalam mengidentifikasi komponen C6 (cipta) pada penguasaan konsep. Tetapi ada kemungkinan bahwa siswa pada kelas kontrol mengalami kemajuan pada saat pembelajaran submateri viskositas dibandingkan dengan kelas eksperimen yang proses pembelajarannya dengan menganalisa konsep melalui video virtual.

Pengaruh penggunaan media virtual dalam pembelajaran kooperatif tipe STAD, digunakan dua buah jenis media virtual yakni laboratorium virtual untuk tiga sub-materi yakni hukum utama hidrostatis, tekanan hidrostatis, dan hukum Archimedes, dan video virtual digunakan untuk sub-materi hukum pascall, gejala kapilaritas dan tegangan permukaan, serta viskositas dan hukum stokes. Pengaruh laboratorium virtual pada proses pembelajaran di kelas eksperimen lebih tinggi 0,23 poin dibandingkan dengan video virtual yang datanya dapat dilihat dari grafik 3. Hal ini diidentifikasi dari kemampuan siswa mengerjakan soal-soal penguasaan konsep yang berhubungan dengan sub-sub materi yang praktikum pada pembelajaran kooperatifnya dilaksanakan menggunakan laboratorium virtual. Sedangkan pembelajaran yang menggunakan video virtual berupa simulasi virtual dari sub-sub materi yang tidak dapat dipraktikumkan memiliki hasil yang tidak jauh berbeda dengan penggunaan laboratorium virtual.

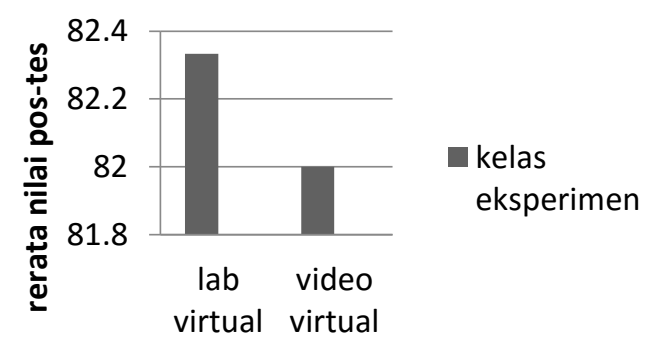

Grafik 3. Data pengaruh lab virtual dan video virtual pada kelas eksperimen. 
Model pembelajaran kooperatif tipe STAD dianggap sebagai model pembelajaran yang sesuai dengan komponen-komponen penguasaan konsep siswa. Model pembelajaran kooperatif juga sesuai dengan pembelajaran untuk materi-materi yang konkrit dan abstrak seperti fisika. Hal ini sesuai dengan kumpulan-kumpulan penelitian dalam jurnal yang ditulis oleh Effandi (2006) yang dimana penelitian tersebut menyatakan bahwa model pembelajaran kooperatif berhasil dalam meningkatkan kemampuan (skill) siswa di bidang sains dan matematika (Zakaria and Iksan. 2006). Hasil ini sejalan dengan hasil penelitian yang dilakukan oleh peneliti mengenai peningkatan penguasaan konsep yang dimiliki siswa akibat pengaruh dari model pembelajaran kooperatif tipe STAD dengan media virtual. Tetapi untuk peningkatan penguasaan konsep pada komponen kognitif C6, model pembelajaran kooperatif tipe STAD tidak mempengaruhi peningkatannya terlalu besar, melainkan menggunakan model pembelajaran langsung juga dapat meningkatkan kognitif mencipta mereka. sedangkan untuk peningkatan penguasaan konsep pada materi hukum Archimedes dan Viskositas, model pembelajaran kooperatif tipe STAD dengan media virtual dan model pembelajaran langsung memiliki pengaruh yang sama terhadap peningkatannya.

\section{PENUTUP}

Penerapan model pembelajaran kooperatif tipe STAD dengan media virtual berpengaruh terhadap penguasaan konsep fisika siswa pada materi fluida statis secara signifikan. Pembelajaran dengan model pembelajaran kooperatif dengan media virtual mampu meningkatkan kemampuan penguasaan konsep fisika siswa pada sub-materi hukum utama hidrostatis, tekanan hidrostatis, hukum paskal, dan hukum stokes serta gejala kapilaritas dan tegangan permukaan. Sedangkan untuk sub-materi hukum Archimedes dan viskositas, baik model pembelajaran kooperatif tipe STAD dengan media virtual dan model pembelajaran langsung memiliki pengaruh yang sama terhadap peningkatanya. Sedangkan untuk peningkatan penguasaan konsep dari aspek kognitif C1 sampai C5 dipengaruhi secara signifikan oleh model pembelajaran kooperatif tipe STAD dengan media virtual sedangkan untuk aspek C6 peningkatannya lebih dipengaruhi oleh model pembelajaran langsung.

\section{UCAPAN TERIMA KASIH}

Terima kasih disampaikan kepada Tim Hibah Penelitian Strategis Nasional Kemenristek Dikti Tahun 2016 yang telah melibatkan kami dalam penelitiannya, membimbing dan mengajarkan banyak hal, serta memfasilitasi semua proses hingga publikasi ilmiah bersama. Terima kasih juga disampaikan kepada Bapak kepala SMAN 07 Mataram serta Bapak
Budi Harto, S.Pd selaku guru mata pelajaran fisika dan seluruh kelas XI tahun ajaran 2015/2016 yang telah ikut serta dalam penelitian ini.

\section{REFERENSI}

[1] Mason, A., \& Singh, C. (2016). Using categorization of problems as an instructional tool to help introductory students learn physics. Physics Education, 51(2), 025009.

[2] Lindstrøm, C., \& Sharma, M. D. (2009). Link maps and map meetings: Scaffolding student learning. Physical Review Special Topics-Physics Education Research, 5(1), 010102.

[3] Departemen Pendidikan Nasional, Standar Kompetensi Kurikulum 2004 Mata Pelajaran Fisika SMA. Jakarata: Pusat Kurikulum Balitbang Depdiknas, 2003.

[4] Zakaria, E. (2009). Promoting cooperative learning in science and mathematics education: A Malaysian perspective. Colección Digital Eudoxus, (22).

[5] Kauertz, A., Neumann, K., \& Haertig, H. (2012). Competence in science education. In Second international handbook of science education (pp. 711-721). Springer Netherlands.

[6] Valle, R. C., Normandeau, S., \& Gonzalez, G. R. (2015). Education at a glance interim report: update of employment and educational attainment indicators. Paris: OCDE, Jan.

[7] Zacharia, Z. C., \& Constantinou, C. P. (2008), Comparing the influence of physical and virtual manipulatives in the context of the Physics by Inquiry curriculum: The case of undergraduate students' conceptual understanding of heat and temperature. American Journal of Physics, 76(4), 425-430.

[8] H. Lam, B. P. Li, M. 2005. Cooperative Learning. The Hong Kong Institute of Education.

[9] Slavin, R. E. (1990). Cooperative learning: Theory, research, and practice. Prentice-Hall.

[10] Cheah, H. M., \& Lim, K. Y. (2016). Mediating approaches to the use of ICT in teaching and learning through the lenses of 'craft'and 'industrial'educator. Journal of Computers in Education, 3(1), 21-31.

[11] Herga, N. R., Čagran, B., \& Dinevski, D. (2016). Virtual Laboratory in the Role of Dynamic Visualisation for Better Understanding of Chemistry in Primary School. Eurasia Journal of Mathematics, Science \& Technology Education, 12(3), 593-608.

[12] De Jong, T., Linn, M. C., \& Zacharia, Z. C. (2013). Physical and virtual laboratories in science and engineering education. Science, 340(6130), 305-308.

[13] Brown, A. L., \& Palincsar, A. S. (1989). Guided, cooperative learning and individual knowledge acquisition. Knowing, learning, and instruction: Essays in honor of Robert Glaser, 393-451.

[14] Krathwohl, D. R. (2002). A revision of Bloom's taxonomy: An overview. Theory into practice, 41(4), 212-218.

[15] Kost, L. E., Pollock, S. J., \& Finkelstein, N. D. (2009). Characterizing the gender gap in introductory physics. Physical Review Special Topics-Physics Education Research, 5(1), 010101. 


\section{Biografi Penulis}

Nina Nisrina, lahir di Mataram 21 September 1994. Penulis menyelesaikan studinya di SDN 17 Ampenan pada tahun 2006, SMPN 10 Mataram pada tahun 2009, dan SMAN 7 Mataram pada tahun 2012. Kemudian melanjutkan pendidikan S-1 di Universitas Mataram pada program studi pendidikan fisika hingga meraih gelar sarjana pendidikan pada tahun 2016. 